\title{
ADAM17 wt Allele
}

National Cancer Institute

\section{Source}

National Cancer Institute. ADAM17 wt Allele. NCI Thesaurus. Code C49722.

Human ADAM17 wild-type allele is located within 2p25 and is approximately $66 \mathrm{~kb}$ in length. This allele, which encodes ADAM17 protein, is involved in the cleavage of membrane-bound cell-surface proteins to release their mature soluble forms. 